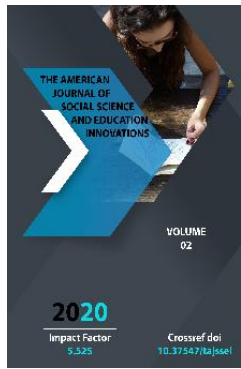

Journal Website: http://usajournalshub.c om/index,php/tajssei

Copyright: Original content from this work may be used under the terms of the creative commons attributes 4.0 licence.

\section{Pedagogical Basis And Organization Of Distance Learning In Modern Education}

\author{
Eshnazarova Margubahon Yunusalievna \\ Candidate Of Pedagogical Sciences, Associate Professor, Namangan State University, \\ Department Of Applied Mathematics, Namangan, Uzbekistan. \\ Toshboev Sayfiddin Muhammadinovich \\ Lecturer, Department Of Applied Mathematics Namangan State University, Namangan, \\ Uzbekistan
}

\title{
ABSTRACT
}

In this article, the pedagogical foundations of modern innovative technologies are justified, as well as the analysis of the research work carried out by scientists of the republic in the field of distance learning.

\section{KEYWORDS}

Innovative technologies, distance education, distant learning, distance education planning, educational portals, distance education technology, distance education methods, statistics.

\section{INTRODUCTION}

According to the Resolution of the President of the Republic of Uzbekistan dated June 5, 2018 "On additional measures to improve the quality of education in higher education and ensure their active participation in comprehensive reforms in the country" PQ-
3775 requires the introduction of advanced innovative technologies in education.

As the President Sh. Mirziyoyev said: "Training of highly qualified, intelligent, innovative specialists who can compete in the international labor market and meet the 
requirements of the time remains one of the most pressing issues".

The "Strategy of Actions on Five Important Priorities for the Development of Uzbekistan for 2017-2021" adopted by the President of the Republic of Uzbekistan on February 7, 2017 identifies a number of important tasks for higher education. In particular, the development of mechanisms for the integration of education with science and industry, aimed at the development of the social sphere, its implementation, individualization (individualization) of education, independent learning and the development of distance learning, its tools, strengthening teaching students based on new innovative technologies. is one of such urgent tasks.

On May 28, 2020, the UNESCO Office in Almaty organized the fourth webinar on "Distance Education: Methodology and Technical Solutions" during the pandemic "COVID-19". It is this organized webinar that requires us to use innovative technologies in education.

Purpose. To highlight the essence of the concept of distance education and provide an analytical interpretation of the main scientific sources on the subject.

\section{MATERIALS AND METHODS}

Innovative technologies mean innovations and changes in the education system, the pedagogical process and the activities of teachers and students. It is advisable to use mainly pedagogical, distance and mobile learning technologies in the implementation of this process.
The use of such innovative technologies in the educational process has its own characteristics, which include:

- Forcing students to think, create and research independently;

- To increase the motivation of students to science in the learning process;

- Independent creative approach to each issue;

- Regular organization of joint activities of teachers and students.

All educational institutions around the world have moved to a new system of education and have been forced to apply the experience of distance learning on a large scale, including the introduction of distance learning technology in all higher education institutions in Uzbekistan. A Moodle system has been formed on the platforms of higher education institutions, which includes electronic resources for all subjects. Video conferencing and seminars were organized on the Zoom Internet platform. Not only the teacher but also the students gained new skills.

New computer technology tools should be widely used in the educational process so that students acquire the necessary knowledge and sufficient skills in the field of their choice. Establishment of information technology and distance learning centers in educational institutions, the formation of a working group of qualified programmers, designers and experienced teachers, obtaining the necessary tools and software from foreign and developed educational institutions are key factors in the widespread introduction of distance learning.

New innovative technologies based on the use of remote methods are important in achieving this goal. The work done to improve the quality of education, the decisions made, 
show that the use of distance learning in the learning process is one of the most pressing issues.

\section{The concept of distance learning and a brief analysis of scientific sources.}

What is distance learning? How is distance learning different from traditional learning? Do they have advantages?

Accordingly, the definitions given by our scholars to the terms distance learning and distance learning were analyzed.

It is the remote interaction of teachers and students, which is carried out by special means of Internet technology, etc. and involves interactivity.

Begimqulov U. Sh., Djuraev R.X. co-authored by "Informatization of pedagogical education: Theory and practice "in the monograph:" Distance learning is a new form of teaching, which differs from the separate and inseparable forms of teaching from production. It refers to new forms, methods, tools, organization of education, forms of communication between teacher and student, as well as between students.

Distance learning is done in different ways in the world: somewhere it is online learning, in some countries the content of distance learning consists of electronic content. Today there are radically different approaches: one is aimed at complementing traditional education based on distance learning (e-learning, online tests, etc.), and the other is a complete transition to a modern form of education: pedagogical, technological, technical, etc. .z.

Distance learning ( $D L$ ) is an interactive communication between teacher and student using information technology in the learning process, as well as the ability of the student to independently master the given learning material.

Distance learning is a modern form of education, the process of pedagogical communication with the teacher is based on video communication, e-mail and the Internet. Analyzes show that student-teacher collaboration in this style of innovative technology is more effective than other forms of teaching. For example, in a six-week management training course, IBM organizes $75 \%$ of distance learning and $25 \%$ of traditional training. The established course saves $\$ 24$ million, reduces the cost of one-day training by three times (from $\$ 400$ to $\$ 135$ ), and increases the amount of training materials by five times.

The main idea of distance learning methodology is to create an informationeducational environment based on didactic principles, teaching methods, pedagogical technologies and tools (computer information sources, electronic libraries, video courses, books and manuals, etc.).

The essence of the information-educational environment.

In the organization of such an informationeducational environment, the organization of independent educational activities of students through the integration of all higher education institutions into a single network, their access to the Internet, control over the educational process, the organization of electronic document exchange, the creation of special educational and methodological complexes It is necessary to perform such tasks as Information-educational environment is a set of conditions that allow the emergence and development of information interaction 
between teachers, students and informationcommunication technologies, as well as the means and technologies for the collection, storage, transmission and processing of educational and professionally oriented information.

The formation of the information-educational environment in educational institutions has a positive effect on the acceleration of the following factors of the educational process: meeting the needs of participants in the educational process in the rapid acquisition of information on disciplines; Involvement of information and communication technologies in the teaching of specialty subjects in the field; collection and reproduction of educational materials on specialty subjects; make full use of the opportunities of the global network in the learning process, increase motivation, increase interest in learning activities, accelerate the pace of learning activities, activate the learning process of students, improve the organization of the educational process, activate teachers, develop independent learning skills.

\section{RESULT AND DISCUSSION}

In creating this information and educational environment, it is important to create an educational platform for higher education institutions. Platform (fr. Plateforme, plate «flat» + forme «form») is a new modern innovative form of education, an Internet site with the ability to serve learners. The creation of an educational platform helps to organize and organize information logically.

In this regard, it is necessary to pay attention to the following issues, Begimkulov U.Sh., Djuraev R.H. etc.:

- Creation of a single educational platform of education in the field of knowledge on the basis of generalization and development of the achieved positive results;

- Creation of online courses that allow to implement a single information and methodological support of science in the system of continuing education;

- Development of the site of the educational institution or its departments (faculties) as an information and educational site;

- Development of methods for using the resources of the educational platform in the learning process.

- The purpose of the platform is to provide the user with the necessary information in a short time and without excessive actions of transitions between different interfaces:

- The information resources provided must be reliable, scientific, systematic, demonstrative and practical;

- Teaching materials are scientific, not difficult to accept;

- The description of teaching materials should be clear to students

At the same time, information resources should be relevant to the content of the program, consist of tasks and tasks that shape the knowledge, skills and abilities of students, presented in a logical system, conform to the principles of continuity and continuity, and meet the principle of structure.

The resources placed on the educational platform should include theoretical questions and tests to test the knowledge acquired by students, as well as practical assignments, training materials for the platform should serve for easy assimilation of information, disclosure of their content. 


\section{Didactic methods of distance learning.}

In distance learning, based on scientific research such as traditional teaching, the following five general didactic methods of teaching can be distinguished: informationreceptive, reproductive, problem-based, research, and heuristic. Currently, the following basic methods are

The main forms of distance learning can include lectures, seminars, consultations, workshops and independent work.

\section{Features of the organization of distance learning.}

In his research, V. Canavo points out that the following requirements should be taken into account when organizing distance learning courses.

Motivation. It is important to keep the student interested during the learning process, it is important that the goal is clear. If the level of the problem does not match the student's level of preparation, the motivation will quickly decrease.

Setting learning objectives. Before starting work on a computer, a student should know what is required of him. The program should clearly and comprehensively cover the student's learning objectives.

Preparation of training materials. Auxiliary materials (manuals, instructions, recommendations, etc.) prepared by teachers are very effective in the preparation of teaching materials. Training programs organized using a variety of media, printed material, radio or television broadcasts, and the use of video-audio cassettes are required to be verified and approved prior to use.
Transfer of training materials. It is necessary to select a specialist to transmit the electronic version of the materials collected during the course at the required level.

Feedback. One of the most basic requirements is that the student achieves selfassessment (test, on-line, question-answer, exercise, etc.).

Cost. During the learning process, the student should know to what extent he / she is mastering the course materials. Another key aspect of the distance learning course is the existence of a "student-teacher-student" network. In this network, students have the opportunity to determine their level of knowledge by organizing questions and answers, discussions with each other or with the teacher.

One of the most important issues in the organization of distance learning is the selection of professors and teachers. In order to implement this training, teachers must be selected from the most experienced and organizers. This is because distance learning depends in many ways on the knowledge, organizational and managerial characteristics of the teacher. A teacher involved in distance learning should be a skilled educator, a wise counselor, and an experienced manager at the same time.

In our scientific article the theoretical basis of the state of training of specialists, pedagogical bases of its organization by means of remote methods of modern innovative technologies is studied. The requirements for the organization of distance learning, the need to develop an educational platform were studied and analyzed. 


\section{CONCLUSION}

The analysis of the conducted scientific, educational and methodical literature allowed to come to the following conclusions:

1. The rapid introduction of modern innovative technologies in the educational process affects the change in the content and organizational forms of the educational process, as well as leads to the emergence of new forms in the educational process, changes the structure of educational content, the nature of teacher activity.

2. Didactic opportunities of distance learning accelerate the process of mastering subjects in higher education institutions, as well as create educational platforms aimed at developing students' creative and cognitive abilities, increase the efficiency of educational work, the effectiveness of independent learning.

\section{REFERENCES}

1. Abduqodirov A.A., Pardaev A.X. Theory and practice of distance learning. -T .: Fan, 2008. - 145 p.

2. Begimqulov U.Sh., Djuraev R. X. et al. Informatization of pedagogical education: theory and practice. Monograph. http://www.uzpfiti.uz/uz/index.php

3. Gulyamov S.S., Romanov A.N., Alimov R.X., Toroptsov V.S., Xodiev B.Yu., Alimov K.A., Begalov B.A., Grigorovich D.B. Distantsionnoe ekonomicheskoe obrazovanie. Monograph. - T .: Sharq, 2004.- 432C.

4. Muslimov N.A. Theoretical and methodological bases of professional formation of a teacher of vocational education. Ped. fan. Ph.D. ... dis. -T .: O'MKHTTKMOUQTI, 2007. -315 p.
5. Kanavo V. Methodical recommendations for creating a distance learning course through the Internet. www.curator.ru/method.html.

6. http://news.rusoil.net/news/2020-07-23sistemy-distancionnogo-obucheniya-opytvnedreniya-v-ugntu - Website of Ufa State University of Oil and Technology.

7. https://www.britannica.com/topic/distance -learning-Information site on distance learning programs.

8. http://en.wikipedia.org/wiki/Moodle Information on Moodle course management system. 